\title{
INFLUENCE OF ABILITY MATHEMATICS LITERACY AND MOTIVATION TO LEARN MATHEMATICS OF STUDENT TO ABILITY OF PROBLEM SOLVING MATHEMATICS ON SOCIAL ARITHMETIC
}

\author{
Aldila Maysarah Ayusari ${ }^{1)}$ \\ ${ }^{1}$ IAIN Tulungagung, Indonesia \\ Email:
}

\begin{abstract}
ABSTRAK
This study aims to determine the effect of mathematical literacy ability and motivation to learn mathematics on student problem solving abilities. The type of research used is non experiment with research design is survey, where the subjects used are students of class VII I SMP Negeri 4 Tulungagung which amounted to 31 students. Instrument used in this research is motivation questionnaire, observation sheet problem solving ability and script about ability of mathematics literacy. Data collection methods used are test methods, questionnaires and observations. Data analysis technique used is with normality test, multiple regression test, correlation test, and significance test. Based on data analysis, it is known that there is an influence of mathematical literacy ability and student learning motivation motivation (X1 and X2) on math problem solving ability (Y) on social grade arithmetic class VII I SMP N 4 Tulungagung.
\end{abstract}

Keywords : Ability of Mathematical Literacy, Motivation to Learn Math, Math Problem Solving Skills

\section{PENDAHULUAN}

Matematika merupakan mata pelajaran yang dipelajari di sekolah yang memiliki peranan penting dalam kehidupan manusia. Tujuan pembelajaran matematika itu sendiri berdasarkan ketetapan Departemen Pendidikan Nasional (2006 ) dan NCTM (2000:67) yang menetapkan bahwa terdapat lima kompetensi dalam pembelajaran matematika yaitu pemecahan masalah matematis, komunikasi matematis, penalaran matematis, koneksi matematis dan representasi matematis. Gabungan kelima kemapuan tersebut merupakan kemampuan literasi matematika (Delyanti Azzumarito Pulungan,2014 : 75). Dalam Pisa terdapat tujuh kemampuan dasar matematika yang menjadi pokok dalam proses literasi matematis (OECD,2013), yang meliputi :

1. Communicating (komunikasi)

Literasi matematika melibatkan proses komunikasi, sebab dalam proses pemecahan masalah siswa perlu mengutarakan atau mengemukakan gagasan, ketika melakukan penalaran terhadap soal maupun langkah-langkah penyelesaian, selain itu siswa juga perlu menjelaskan hasil pemikiran atau gagasannya kepada orang lain juga dapat memahami hasil pemikirannya. Meliputi :

a. Memahami dan menuliskan informasi yang diketahui dan ditanyakan terkait tujuan soal

b. Menyajikan respon yang mungkin, meliputi :

- Menuliskan rumus yang digunakan untuk menyelesaikan soal 
- Menuliskan langkah - langkah penyelesaian yang mudah

- Menuliskan kesimpulan dari jawaban yang diberikan

2. Mathematising (matematisasi)

Kemampuan literasi matematis juga melibatkan kemampuan matematisasi, yakni kemampuan dalam menerjemahkan bahasa sehari-hari ke dalam bentuk matematika, baik berupa konsep, struktur, membuat asumsi atau pemodelan

3. Representation (representasi)

Kemampuan representasi disini adalah kemampuan dalam merepresentasikan objek - objek matematika seperti grafik, tabel, diagram, gambar, persamaan, rumus, dan bentuk - bentuk konkret lainnya.

4. Reasoning and Argument (penalaran dan argumen)

Kemampuan penalaran dan argument adalah akar dari proses bepikir logis yang dikembangkan untuk menemukan suatu kesimpulan yang dapat memberikan pembenaran terhadap solusi suatu permasalahan. Meliputi :

a. Menghubungkan unsur - unsur masalah yang saling berkaitan.

b. Memberikan alasan logis yang menghasilkan kesimpulan

c. Membuat kesimpulan dari solusi yang diberikan.

5. Devising strategis for solving problem (merancang strategi untuk memecahkan masalah)

Kemampuan ini berkaitan dengan kemampuan seseorang menggunakan matematika untuk memecahkan masalah yang dihadapi. Meliputi :

a. Merencanakan suatu pendekatan atau strategi yang mengarah pada penyelesaian masalah

b. Menjelaskan tahapan atau langkah - langkah penyelesaian soal

c. Menerapkan dan melaksanakan strategi pnyelesaian soal

d. Memeriksa kembali

6. Using symbolic, formal, and technical language and operations (penggunaan simbol, bahasa formal, teknis operasi)

Kemampuan ini melibatkan pemahaman, penafsiran, kemampuan memanipulasi suatu konteks matematika yang digunakan dalam menyelesaikan permasalahan terkait matematika.

7. Using mathematical tools (penggunaan alat matematika)

Kemampuan yang dimaksud adalah mampu menggunakan berbagai macam alat yang dapat membantu proses metematisasi, dan mengetahui keterbatasan alat - alat tersebut.

Kemampuan inilah yang perlu dikuasai oleh siswa agar dapat menggunakan ilmu matematika dalam kehidupan sehari - hari. Namun nyatanya menurut Mudzakir,2006.: 4 bahwa kemampuan literasi matematika siswa saat ini masih rendah dikarenakan kemampuan literasi matematika yang belum dilatih hal ini dikarenakan belum tersedianya soal - soal yang megukur kemampuan literasi matematika. Selain itu, motivasi belajar memiliki peranan penting dalam keberhasilan belajar seseorang. Hal ini sesuai dikutip dari Hamzah B.Uno (2011:23) hakikat motivasi adalah dorongan internal dan eksternal pada siswa - siswa yang sedang belajar untuk mengadakan perubahan tingkah laku, pada umumnya dengan beberapa indikator atau unsur yang mendukung (Yeni Heryani,2017:65). Sedangkan menurut Sudirman 
.A.M (2011:83) mengemukakan ciri-ciri motivasi yang ada pada siswa diantaranya adalah :

1. Tekun menghadapi tugas (dapat bekerja terus menerus dalam waktu yang lama, tidak pernah berhenti sebelum selesai.)

2. Ulet menghadapi kesulitan (tidak lekas putus asa) tidak memerlukan dorongan dari luar untuk berprestasi sebaik mungkin (tidak cepat puas dengan prestasi yang telah dicapainya).

3. Menunjukkan minat terhadapa bermacam-macam masalah.

4. Lebih senang bekerja mandiri.

5. Cepat bosan pad tugas yang rutin (hal-hal yang bersifat mekanis, berulangulang begitu saja, sehingga kuhal yang diyakini iturang efektif)

6. Dapat mempertahankan pendapatnya (kalau sudah yakin akan sesuatu)

7. Tidak mudah melepaskan hal

8. Senang mencari dan memecahkan masalah soal-soal.

Jika dilihat dari,uraian indikator tersebut maka dapat dikatakan bahwa rendahnya kemampuan literasi matematika selain karena latihan terhadap kemampuan literasi matematika masih kurang dan motivasi matematis siswa yang masih rendah dikarenakan mindset bahwa matematika merupakan mata pelajaran yang sulit dan membosankan yang belum terhapus dari diri siswa.

Mengetahui begitu pentingnya kemampuan literasi matematis untuk siswa, maka diperlukan upaya peninjauan tentang pengaruh motivasi belajar siswa terhadap kemampuan literasi matematis siwa, sehingga bila memang motivasi belajar matematika berpengaruh terhadap kemampuan literasi matematis, maka dapat dilanjutkan dengan usaha dalam meningkatkan motivasi belajar siswa guna meningkatkan kemampuan literasi matematis siswa.

Menurut Wardhani dan Rumiati (2011) menulis bahwa kemampuan literasi matematis diartikan sebagai kemampuan seseorang (dalam hal ini, siswa) untuk merumuskan, menerapkan dan menafsirkan matematika dalam berbagai konteks, termasuk kemampuan melakukan penalaran secara matematis dan menggunakan konsep, prosedur, dan fakta untuk menggambarkan, menjelaskan atau memperkirakan fenomena/kejadian. Sejalan dengan hal tersbut Suyitno Literasi matematika membantu seseorang untuk memahami peran atau kegunaan matematika didalam kehidupan sehari-hari sekaligus menggunakannya untuk membuat keputusan - keputusan yang tepat sebagai warga negara yang membangun, peduli, dan berpikir.

Berpikir disini maksudnya adalah bagaimana siswa dapat menyelesaikan suatu masalah yang sedang dihadapi. Sebagaimana yang diungkapkan Sumarmo (dalam Fauziah, 2010: 2) bahwa, "Proses berpikir dalam pemecahan masalah memerlukan kemampuan mengorganisasikan strategi. Hal ini akan melatih orang berpikir kritis, logis, kreatif yang sangat diperlukan dalam menghadapi perkembangan masyarakat" (Ersa Novianti,2016:402). Sumarmo (dalam Fauziah,2010) mengemukakan, pentingnya kemampuan pemecahan masalah juga dilatarbelakangi oleh pandangan bahwa kegiatan pemecahan masalah adalah 
jantung kegiatan matematika (Yeni Heryani,2017:63). Masalah juga dipandang sebagai hal yang paling dekat dengan kehidupan manusia. Bahkan tujuan dari kemampuan pemecahan masalah itu sendiri melatarbelakangi tujuan dari matematika, yaitu supaya siswa mampu menyelesaikan masalah. Menurut George Polya dalam bukunya How To Solve It mengatakan bahwa terdapat empat langkah dalam penyelesaian masalah yaitu memahami masalah, merencanakan pemecahan masalah, melaksanakan rencana dan melihat kembali.

Kemampuan pemecahan masalah matematika siswa yang rendah disebabkan oleh beberapa faktor, salah satunya motivasi belajar. Berdasarkan Sardiman, 2001 motivasi belajar berasal dari kata motif yang dapat diartikan sebagai kekuatan yang terdapat dalam diri individu, yang menyebabkan individu tersebut bertindak atau berbuat (dalam Himmatul Ulya,2016: 91). Seperti yang dikutip dalam Djamarah 2008 (dalam Himmatul Ulya,2016: 91) motivasi adalah suatu perubahan energi di dalam pribadi seseorang yang ditandai dengan timbulnya perasaan dan reaksi untuk mencapai tujuan. Jadi motivasi belajar adalah kondisi psikologis siswa yang dapat menimbulkan kegiatan belajar dengan senang dan sungguh-sungguh sehingga tujuan yang dikehendaki oleh subyek belajar itu tercapai. Indikator motivasi menurut Uno (2008) yaitu: (1) adanya keinginan berhasil, (2) adanya kebutuhan dalam belajar, (3) adanya cita-cita masa depan, (4) adanya penghargaan dalam belajar untuk siswa, (5) adanya kegiatan yang menarik dalam belajar oleh guru, dan (6) adanya lingkungan yang kondusif.

Jika dilihat keterkaitan antara kemampuan literasi matematika, kemampuan pemacahan masalah dan motivasi belajar matematika dapat dilihat dari ungkapan Callison (2013) menyebutkan bahwa para siswa membutuhkan pengembangan kemampuan praktis matematika seperti pemecahan masalah, membuat hubungan, memahami berbagai representasi dari ide - ide matematika, mengkomunikasikan proses pemikiran mereka, dan menjelaskan penalaranpenalaran yang mereka lakukan.Standar kurikulum matematika sekarang secara eksplisit menekankan hubungan (connection) sebagai salah satu proses penting dalam pembelajaran matematika. Pembelajaran harus membuat siswa dapat mengenal dan menggunakan dalam konteks di luar matematika. Hal ini termasuk membuat hubungan terhadap"dunia nyata", yaitu dunia di luar kelas. Kesulitan kesulita dalam menyelesaikan soal, diperlukan kekuatan dan ketahanan dari siswa sendiri, dimana hal tesebut muncul dari motivasi yang ada pada diri siswa sendiri.

Sehingga dengan adanya pemahaman siswa terkait dengan kehidupan sehari - hari, diharap terasahnya kemampuan literasi matematis siswa selain itu dengan mengetahui bahwa materi yang sedang dipelajarinya berguna bagi kehidupan sehari - hari, akan membuatnya termotivasi untuk mendalaminya lebih dalam lagi.

Seperti dikutip pada (Rogers Pakpahan ,2012:331) bahwa faktor - faktor yang mempengaruhi prestasi siswa Indonesia pada studi PISA 2012 adalah faktor internal yaitu jati diri dan faktor eksternal yaitu kondisi keluarga, kepemilikan sarana belajar, dan kondisi sosial budaya dirumah . Dimana semua itu dapat disebut sebagai faktor munculnya motivasi pada siwa. Studi PISA merupakan studi untuk untuk mengetahui pengetahuan yang penting dikuasai warga negara dan ketrampilan yang dapat dilakukan $(O E C D, 2013)$. Selain itu, Uno Hamzah 
(dalam Subaru Utama Olpado,2017:64) juga menyebutkan bahwa motivasi dapat berperan dalam penguatan belajar apabila seorang anak yang belajar dihadapkan pada suatu masalah yang memerlukan pemecahan, sehingga motivasi perlu dimiliki oleh peserta didik dalam mengembangkan kemampuan pemecahan masalah matematika.

Untuk itu berdasarkan latar belakng yang telah diuraikan, dalam penelitian ini ingin diketahui adakah pengaruh kemampuan literasi matematika dan motivasi belajar matematika terhadap kemampuan pemecahan masalah pada materi aritmatika sosial siswa kelas VII I SMP N 4 Tulungagung?

\section{METODE PENELITIAN}

Jenis penelitian ini adalah non eksperimen dengan desain penelitian adalah desain survai. Teknik analisis data yaitu dengan menggunakan bantuan aplikasi spss 16 dalam uji normalitas dan uji regresi berganda.Dikatakan penelitian survai karena bertitik tolak dari konsep, hipotesis dan teori yang sudah mapan, sehingga lebih bersifat sebagai verifikai atas teori yang sudah tersedia. Sehingga bertitik tolak dari dasar deduktif.

Gambar.1 Desainnya Penelitian Survai

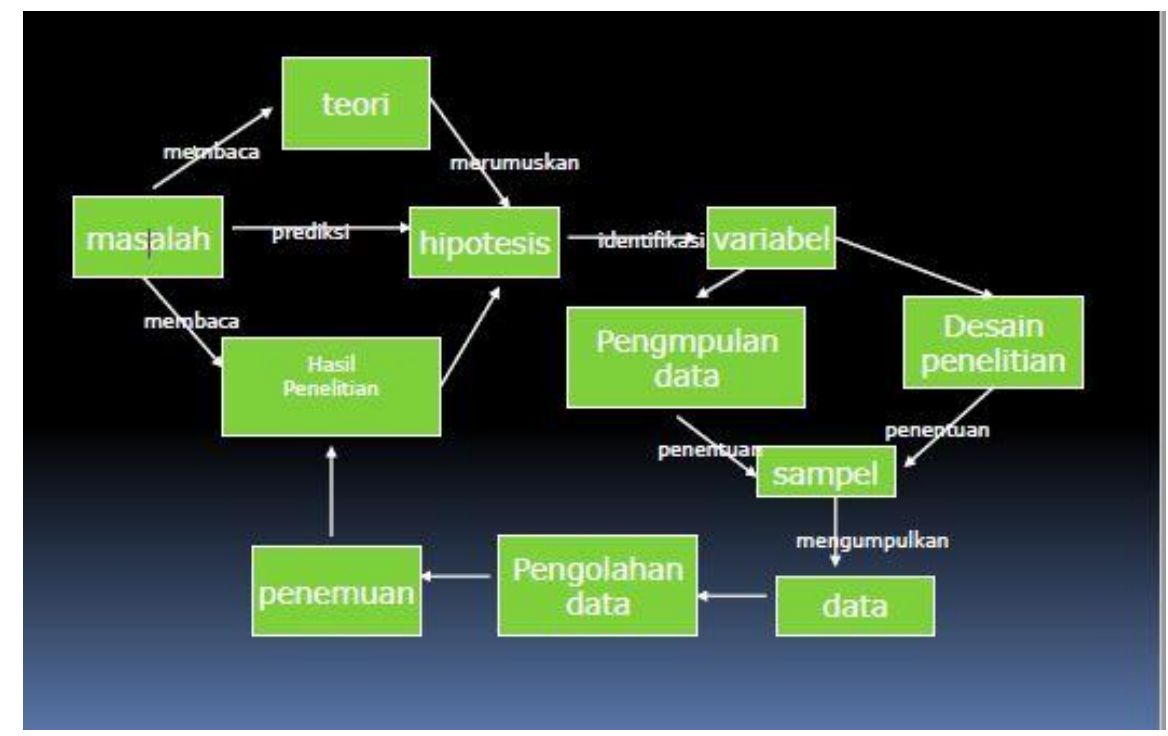

Subyek dalam penelitian ini adalah siswa kelas VII I SMP Negeri 4 Tulungagung Tahun Pelajaran 2017/2018 yang berjumlah 31 sisawa dan 3 diantaranya sebagai sampel penelitian. Dalam penentuan 3 sampel tersebut dilakukan dengan teknik purposive sampling yaitu penentuan sampel didasarkan pada pertimbangan-pertimbangan tertentu, adapun pertimbangan yang dilakukan berdasarkan pada hasil kemampuan literasi matematika dan motivasi belajar matematika terhadap kemampuan pemecahan masalah matematika pada materi aritmatika sosial. 


\section{HASIL PENELITIAN DAN PEMBAHASAN}

Uji Normalitas

Uji normalitas nilai merupakan pengujian yang dilakukan untuk mengetahui bentuk distribusi data (nilai) yang digunakan dalam penelitian.Uji normalitas dalam penelitian ini dilakukan dengan bantuan program SPSS 16. Berikut ini hasil perhitungan uji normalitas nilai.

Tabel.1 Hasil Uji Normalitas dengan SPSS 16.

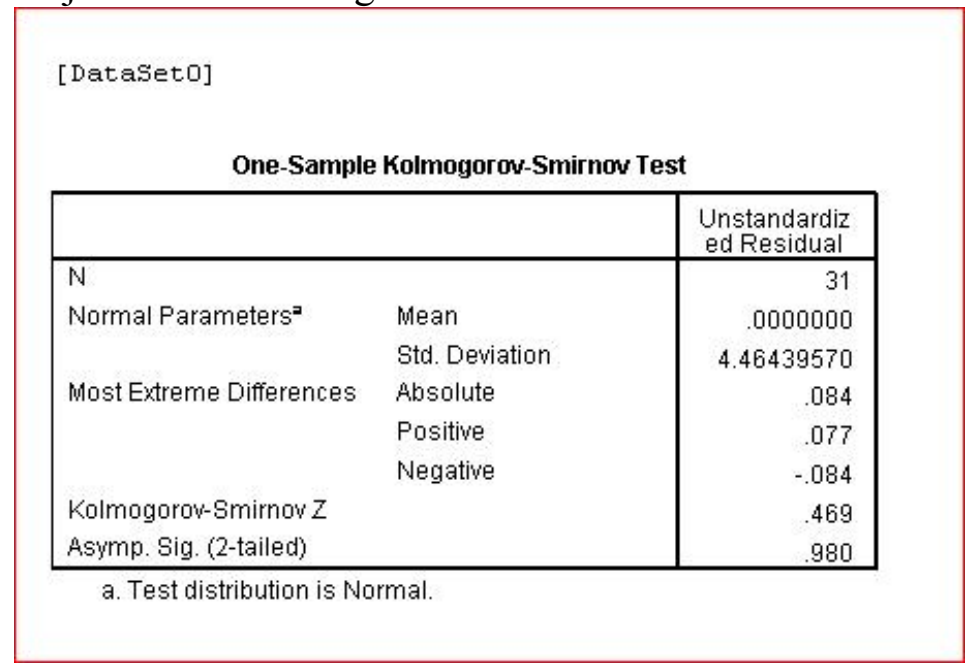

Berdasarkan Tabel.1 ,dapat disimpulkan bahwa data berdistribusi normal, karena nilai signifikansi lebih dari 0,005 .

\section{Uji Regresi Berganda}

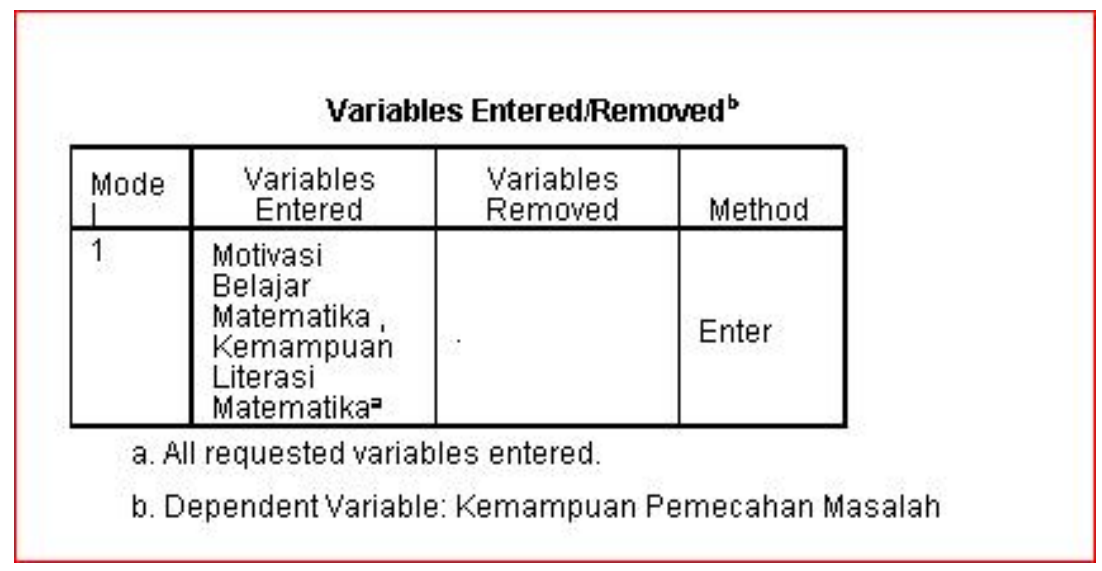

Tabel.2 menjelaskan tentang variabel yangdimasukkan dan metode yang digunakan. Dalam penelitian ini yang variabel digunakan adalah kemampuan literasi matematika dan motivasi belajar matematika siswa serta kemampuan pemecahan masalah matematika. Dan metode yang digunakan adalah metode enter.

Tabel.3 Hasil Nilai Korelasi dengan SPSS 16 


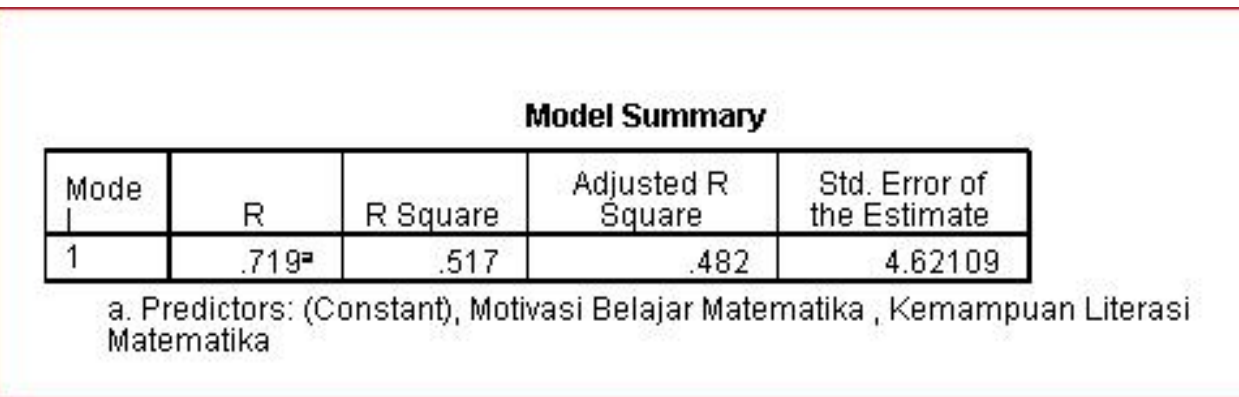

Tabel.3 menjelaskan besarnya nilai korelasi atau hubungan (R) yaitu 0,719. Dari out put tersebut diperoleh koefisien determinasi (R Square) sebesar 0,517 yang berarti variabel bebas (kemampuan literasi matematika dan motivasi belajar matematika siswa) terhadap variabel terikat (kemampuan pemecahan masalah) adalah sebesar $5,17 \%$.

Tabel.4 Nilai Sigifikansi dengan SPSS 16

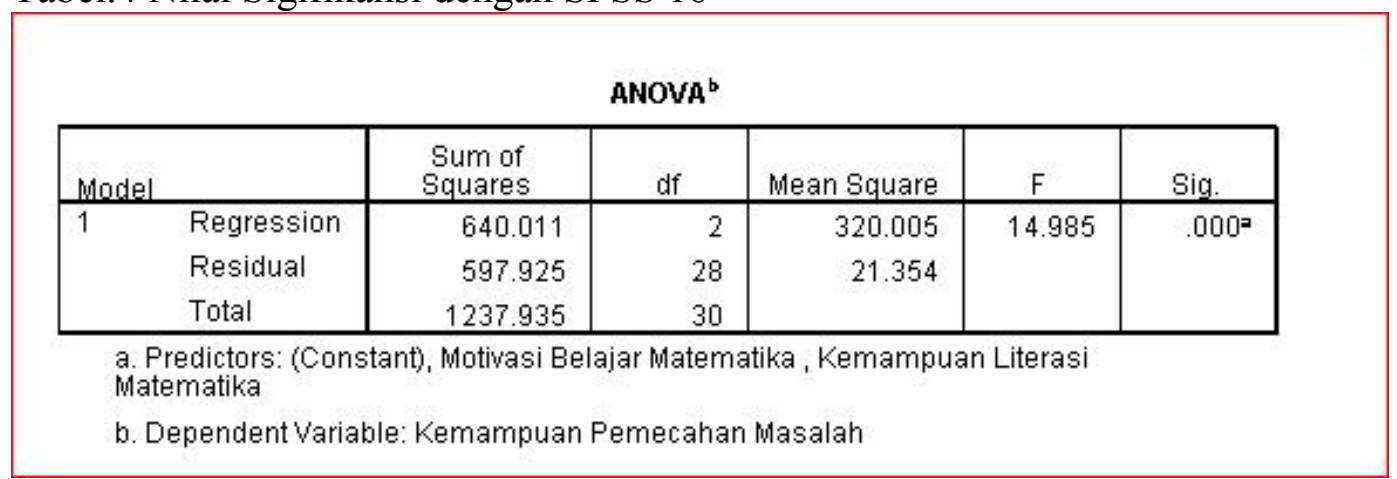

Dari output tersebut diketahui bahwa nilai $\mathrm{F}$ hitung $=14,985$ dengan tingkat signifikansi sebesar $0,000<0,05$. Maka model regresi dapat dipakai untuk memprediksi variabel kemampuan pemecahan masalah atau dengan kata lain ada pengaruh kemampuan literasi matematika dan motivasi belajar matematika siswa (X1 dan X2) terhadap kemampuan pemecahan masalah matematika (Y) pada materi aritmatika sosial kelas VII.

\section{SIMPULAN DAN SARAN Simpulan}

Nilai korelasi atau hubungan (R) yaitu 0,719. Dari out put tersebut diperoleh koefisien determinasi (R Square) sebesar 0,517 yang berarti variabel bebas (kemampuan literasi matematika dan motivasi belajar matematika siswa) terhadap variabel terikat (kemampuan pemecahan masalah) adalah sebesar 5,17\%. Sedangkan untuk nilai sigifikansi dengan uji annova diperoleh nilai $\mathrm{F}$ hitung $=$ 14,985 dengan tingkat signifikansi sebesar $0,000<0,05$. Maka model regresi dapat dipakai untuk memprediksi variabel kemampuan pemecahan masalah atau dengan kata lain ada pengaruh kemampuan literasi matematika dan motivasi 
belajar matematika siswa (X1 dan X2) terhadap kemampuan pemecahan masalah matematika (Y) pada materi aritmatika sosial kelas VII I SMP N 4 Tulungagung.

Saran

Diharapkan kepada guru untuk lebih sering memberikan latihan - latihan soal bertipe PISA demi meningkatkan kemampuan literai matamatis siswa, disamping dengan memberikan pembelajaran yang bervariasi guna meningkatkan motivasi belajar siswa. Selain itu motivasi dapat ditingkatkan dengan memberikan informasi kepada siswa tentang kegunaan materi yang dipelajari, atau dengan mengaitkan materi di bidang sosial, budaya, maupun agama. Untuk kemampuan pemecahan masalah, guru dharapkan lebih sering memberi latihan soal uraian yang dimana dapat membentuk pola pikir siswa dalam menyelesaikan suatu permasalahan.

\section{DAFTAR PUSTAKA}

Elentrian,Helva dan Resvita Febriana.(2017) " Kemampuan Menyelesaikan Soal Matematika (PISA) dan Daya Juang Siswa dalam Menghadapi UN " Seminar Matematika dan Pendidikan Matematika UNY

Heryani, Yeni, and Subaru Utama Olpado. (2017)"Korelasi antara Motivasi Belajar dengan Kemampuan Pemecahan Masalah Matematik Peserta Didik Menggunakan Model Problem Based Learning (PBL)." JP3M (Jurnal Penelitian Pendidikan dan Pengajaran Matematika) 3.1

Novianti, Ersa, and Yedi Kurniadi. (2016)"PENDEKATAN EKSPLORATIF UNTUK MENINGKATKAN KEMAMPUAN PEMECAHAN MASALAH MATEMATIS DAN MOTIVASI BELAJAR SISWA." Pena Ilmiah 1.1: 401-410.

Pakpahan, Rogers. (2017)."Faktor-faktor Yang Memengaruhi Capaian Literasi Matematika Siswa Indonesia Dalam Pisa 2012." Jurnal Pendidikan dan Kebudayaan 1.3: 331-348.

Pulungan, Delyanti Azzumarito. (2014)"Pengembangan Instrumen Tes Literasi Matematika Model Pisa." Journal of Educational Research and Evaluation 3.2

Ulya, Himmatul. (2016). "Profil kemampuan pemecahan masalah siswa bermotivasi belajar tinggi berdasarkan ideal problem solving." Jurnal Konseling Gusjigang 2.1 